\title{
A Possible Common Cell Surface Autoantigen in Islet $\beta$-Cells and Thyroid Follicular Cells in Patients with Non-Insulin Dependent Diabetes Mellitus and Chronic Thyroiditis
}

\author{
TAKAHIKo IGAWA, HAJIME NAKABAYASHI, RYOYU TAKEDA, AND YORIAKI KURATA* \\ Department of Internal Medicine II, School of Medicine, and *Department of Pathophysiology, \\ Cancer Research Institute, Kanazawa University, Kanazawa 920, Japan
}

\begin{abstract}
By an indirect immunofluorescence method with In-111 cells (hamster insulinoma cell line), circulating islet cell surface antibodies (ICSA) were detected in 7 (20\%) out of 36 patients with noninsulin dependent diabetes mellitus (NIDDM), 9\% of 68 chronic thyroiditis (CT) patients, or $16 \%$ of 19 NIDDM patients associated with CT, but not in 18 normal subjects. Sera from five out of nine ICSApositive patients examined further also showed cell-surface immunofluorescence on TPC-1 cells (human thyroid papillary adenocarcinoma cell line), and prior absorption of the sera with In-111 cells abolished the immunofluorescence. The $64 \mathrm{kDa}$ protein from In-111 cells or human thyroid follicular cells was immunoprecipitated with ICSA-positive sera. In one case of NIDDM associated with CT, $64 \mathrm{kDa}$ protein was detected in both cells. The results indicate that some ICSA in NIDDM patients recognize the same or a very closely-related autoantigen(s) in both islet $\beta$-cells and thyroid follicular cells, suggesting an explanation, at least in part, for the autoimmune mechanism(s) in clinical association of NIDDM and CT.
\end{abstract}

Key words: Islet cell surface antibodies (ICSA), Organ-specific autoantigen, Autoimmune polyglandular endocrinopathy

(Endocrine Journal 43: 299-306, 1996)

ISLET CELL specific autoantibodies such as islet cell cytoplasmic antibodies (ICA) [1,2] and islet cell surface antibodies (ICSA) [3, 4] have frequently been found in sera of insulin dependent diabetes mellitus (IDDM) patients, suggesting autoimmune mechanisms in the pathogenesis of IDDM. Furthermore, patients with chronic thyroiditis (CT), a representative organ-specific autoimmune disease, have been known to have circulating antibodies to thyroglobulin or follicular cell microsome (namely thyroid peroxidase) [see review 5]. These and oth-

Received: June 12, 1995

Accepted: February 13, 1996

Correspondence to: Dr. Hajime NAKABAYASHI, Department of Internal Medicine II, School of Medicine, Kanazawa University, 13-1 Takara-machi, Kanazawa, Ishikawa 920, Japan er various organ specific autoantibodies have also been detected in sera of IDDM patients [6], and the clinical association of various endocrine diseases, particularly a high incidence of CT, in IDDM patients has been reported [7].

On the other hand, the clinical association of noninsulin dependent diabetes mellitus (NIDDM), the other type of diabetes thought generally to be unrelated to autoimmune mechanisms and CT, is not rare in Japanese [8]. In addition, ICSA are detected in sera of NIDDM patients and CT patients as well $[9,10]$, and ICSA are known to damage islet $\beta$-cells specifically [11]. Thus, in the present study, we have examined whether antigens recognized by ICSA in NIDDM and/or CT patients are also located in thyroid follicular cells. 


\section{Subjects and Methods}

\section{Patients}

Serum samples were obtained from 36 patients (18 women and 18 men; 31-61 years old, mean of 52 years old) with NIDDM, 68 patients (67 women and 1 man; 16-71 years old, mean of 59 years old) with CT, 19 patients (14 women and 5 men; 34-79 years old, mean of 60 years old) with NIDDMassociated CT and 18 normal control subjects $(8$ women and 10 men; 21-59 years old, mean of 49 years old). The diagnosis and classification of diabetes mellitus (DM) were performed according to criteria reported by the World Health Organization [12]. The diagnosis of CT in all cases was proven histologically with needle biopsy specimens.

\section{Detection of ICSA}

In-111 cells [13] cultured on a tissue culture slide (Lab-Tek 8 chamber Fixed Gasket, Naperville, IL., U.S.A.) for 2 days at $37^{\circ} \mathrm{C}$ were fixed with acetone for $1 \mathrm{~min}$ at room temperature, and incubated with phosphate buffered saline (PBS; $10 \mathrm{mM}, \mathrm{pH} 7.3$ ) containing $0.5 \%$ bovine serum albumin (BSA) (Fraction V; Armour Pharmaceutical Company, Kankakee, IL., U.S.A.) at $37{ }^{\circ} \mathrm{C}$ for $15 \mathrm{~min}$. The cells were reacted with $50 \mu l$ of test serum diluted at 1:5 in PBS for $60 \mathrm{~min}$. Staining was done by incubating with $50 \mu l$ of biotinylated goat anti-human IgG $(2 \mu \mathrm{g} / \mathrm{ml})$ (Vector Laboratories, Inc., Burlingame, CA., U.S.A.) at $37^{\circ} \mathrm{C}$ for $30 \mathrm{~min}$ and then with $50 \mu l$ of fluorescein isothiocyanate (FITC)conjugated avidin $(4 \mu \mathrm{g} / \mathrm{ml})$ (Vector Laboratories, Inc.) for $15 \mathrm{~min}$. After each incubation, the cells were washed with PBS. The number of positive cells having immunofluorescence on the cell surface was counted under a fluorescence microscope. Serum showing more than 30 cells with clear immunofluorescence out of 100 total cells was judged as ICSA-positive. Negative serum showed hardly any staining. As to the cases in Table 1, serum showing positive but somewhat weak fluorescence was particularly expressed as weak-positive.

The specificity of ICSA was examined as follows: Two milliliters of ICSA-positive serum was mixed with an equal volume of saturated ammonium sulfate and stirred at $4{ }^{\circ} \mathrm{C}$ for $30 \mathrm{~min}$. The resultant precipitate, immunoglobulin (IG) fraction, was dissolved in $1 \mathrm{ml}$ of PBS and dialyzed to PBS extensively. Fifty microliters of IG fraction diluted 1:10 in PBS was mixed with an equal volume of In-111 cells precipitated by centrifugation at $140 \times$ $\mathrm{g}$ for $1 \mathrm{~min}$, and incubated at $37^{\circ} \mathrm{C}$ for $60 \mathrm{~min}$. The supernatant was tested for reactivity with In111 cells as described above. The IG fraction was also examined for reactivity with TPC-1 cells by an indirect immunofluorescence method before and after absorption with In-111 cells. A TPC- 1 cell line was established from human thyroid papillary adenocarcinoma found in a 28-year-old man in 1983, and shown to have the same antigenecity as normal human thyroid follicular cells and to produce up to $3.7 \mathrm{ng} / \mathrm{ml}$ of thyroglobulin in the culture medium [14].

\section{Detection of ICA}

Pancreas tissues from a normal subject with blood group $\mathrm{O}$ were fixed in Bovin's fixative fluid, then washed in $50 \%$ alcohol and embedded in paraffin blocks. $4 \mu \mathrm{m}$ thin sections were placed on microscope slides. The substrate was incubated with ICSA-positive serum or IG fraction (diluted 1:10 in PBS) for 30 min, washed with PBS and allowed to react with FITC-conjugated anti-human IgG at $37^{\circ} \mathrm{C}$ for $30 \mathrm{~min}$. Each section was examined under a fluorescence microscope [15]. In our preliminary study, the results obtained by this method were consistent with those obtained by the method reported by Bottazzo et al. [1].

\section{Detection of ICSA-corresponding antigen(s) in In-111 cells}

In-111 cells $\left(3.6 \times 10^{6}\right)$ were homogenized with 1 $\mathrm{ml}$ of $0.5 \%$ Nonidet P-40 (NP-40; Sigma, St. Louis, MO., U.S.A.) containing $0.15 \mathrm{M} \mathrm{NaCl}, 5 \mathrm{mM}$ EDTA, $0.1 \%$ sodium dodecyl sulfate (SDS), 1,000 kallikrein inhibitor units $/ \mathrm{ml}$ aprotinin and $2 \mathrm{mM}$ phenylmethylsulfonyl fluoride (PMSF) (NP-40 Buffer) for 5 min and then stirred at $4{ }^{\circ} \mathrm{C}$ for $90 \mathrm{~min}$ [16]. The suspension was centrifuged at $3,000 \times \mathrm{g}$ at $4{ }^{\circ} \mathrm{C}$ for $10 \mathrm{~min}$, and the insoluble material was removed by centrifugation $(90 \mathrm{~min}$ at $10,000 \times \mathrm{g}$ ). The protein concentration of the lysate was adjusted to 1.4 $\mathrm{mg} / \mathrm{ml}$ by the Lowry method [17]. Fifty microliters of the lysate was radiolabeled with $1 \mathrm{mCi}$ $\mathrm{Na}^{125}$ I (DuPont, Wilmington, DEL., U.S.A.) by the 
chlolamine-T method [18], and the first peak eluted through a PD-10 column (Pharmacia Fine Chemical AB, Uppsala, Sweden) was used as radiolabeled proteins. One hundred microliters of IG fraction at a protein concentration of $1.4 \mathrm{mg} /$ $\mathrm{m} l$ was mixed with an equal volume of radiolabeled proteins, incubated at $4{ }^{\circ} \mathrm{C}$ for $60 \mathrm{~min}$, and further reacted with $200 \mu l$ of protein A-Sepharose CL 4B (Pharmacia Fine Chemicals AB) containing $1 \mu \mathrm{g} / \mathrm{ml}$ of protein $\mathrm{A}$ at $4{ }^{\circ} \mathrm{C}$ for $30 \mathrm{~min}$ [19]. The precipitate was washed with $20 \mathrm{mM}$ Tris- $\mathrm{HCl}(\mathrm{pH}$ 8.1) containing $100 \mathrm{mM} \mathrm{NaCl}, 1 \mathrm{mM}$ EDTA and $0.5 \%$ NP-40, and boiled in the sample buffer (containing $0.2 \mathrm{mM}$ Tris- $\mathrm{HCl}$ ( $\mathrm{pH} 6.8), 0.2 \%$ SDS, 50 $\mathrm{mM}$ dithiothreitol, $10 \%$ glycerol and $5 \mathrm{mg}$ bromophenol blue) for SDS polyacrylamide gel electrophoresis (SDS-PAGE) for $5 \mathrm{~min}$ [16]. The supernatant was analyzed by $7.5 \%$ SDS-PAGE and autoradiography [20].

\section{Detection of ICSA-corresponding antigen(s) in thyroid follicular cell membranes}

Cell membrane antigens of the normal thyroid were prepared by Kurata's method [21] with minor modification using autopsy material from subjects without DM or autoimmune diseases either in the past or in the family history. Briefly, the thyroid tissue was homogenized in PBS and centrifuged at $10,000 \times \mathrm{g}$ for $30 \mathrm{~min}$. After homogenization and centrifugation of the precipitate were repeated, the particulate fraction was solubilized in $0.5 \% \mathrm{NP}-40$ Buffer at $4{ }^{\circ} \mathrm{C}$ for $48 \mathrm{~h}$. The supernatant was mixed with 10 volumes of cold acetone and left at $-20^{\circ} \mathrm{C}$ overnight. The resulting precipitate was dissolved in PBS and analyzed by gelfiltration on a Sephacryl 300 column (Pharmacia Fine Chemicals $A B)$. A protein peak was obtained in the proximity of 64 kilodaltons $(\mathrm{kDa})$ as thyroid cell membrane antigens. This fraction was radiolabeled with $\mathrm{Na}^{125} \mathrm{I}$ by the chlolamine- $\mathrm{T}$ method and the reactivity with serum IG fraction was analyzed as described under Detection of ICSA-corresponding antigen(s) in In-111 cells.

\section{Verification of the organ specificity of ICSA}

Normal liver was obtained from an autopsy case without DM or autoimmune diseases either in the past or in the family history. The tissue was subjected to the preparation of membrane antigens, radiolabeled, and further processed for analysis by SDS-PAGE and autoradiography as described above.

Detection of anti-BSA antibodies in the serum IG fraction was further performed with ${ }^{125}$ I-BSA in the same immunoprecipitation manner as described above.

\section{Results}

By an indirect immunofluorescence method, ICSA in the patient's serum were detected as shown in Fig. 1. ICSA-positive sera were found in seven out of 36 patients with NIDDM (20\%), in 6/68 (9\%) CT, in $3 / 19(16 \%)$ NIDDM and CT, but no ICSA were found in any serum of 18 normal subjects. Prior absorption of each positive serum with In111 cells abolished the immunofluorescence on In-111 cells (Fig. 1), indicating the specificity of ICSA for islet cells. Since ICSA were found in patients with NIDDM and/or CT, the IG fractions obtained from 9 cases having a sufficient volume of their sera were further tested for the reactivity with TPC-1 cells (Fig. 1). Five out of nine ICSApositive sera examined were found to be positive (Table 1); cell-surface immunofluorescence on TPC1 cells was observed in $1 / 3$ NIDDM, in $2 / 3 \mathrm{CT}$, and in $2 / 3$ NIDDM and CT. The immunofluorescence was abolished after absorption of IG fraction
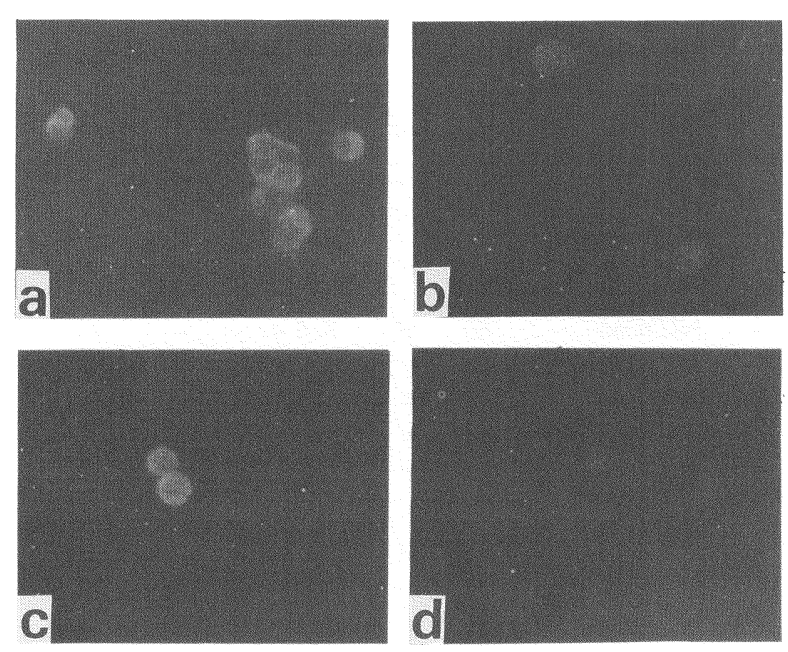

Fig. 1. Fluorescence micrograph of In-111 cells before (a) and after (b) absorption of ICSA-positive immunoglobulins with In-111 cells, and also of TPC -1 cells ( $c$ and d, respectively). 


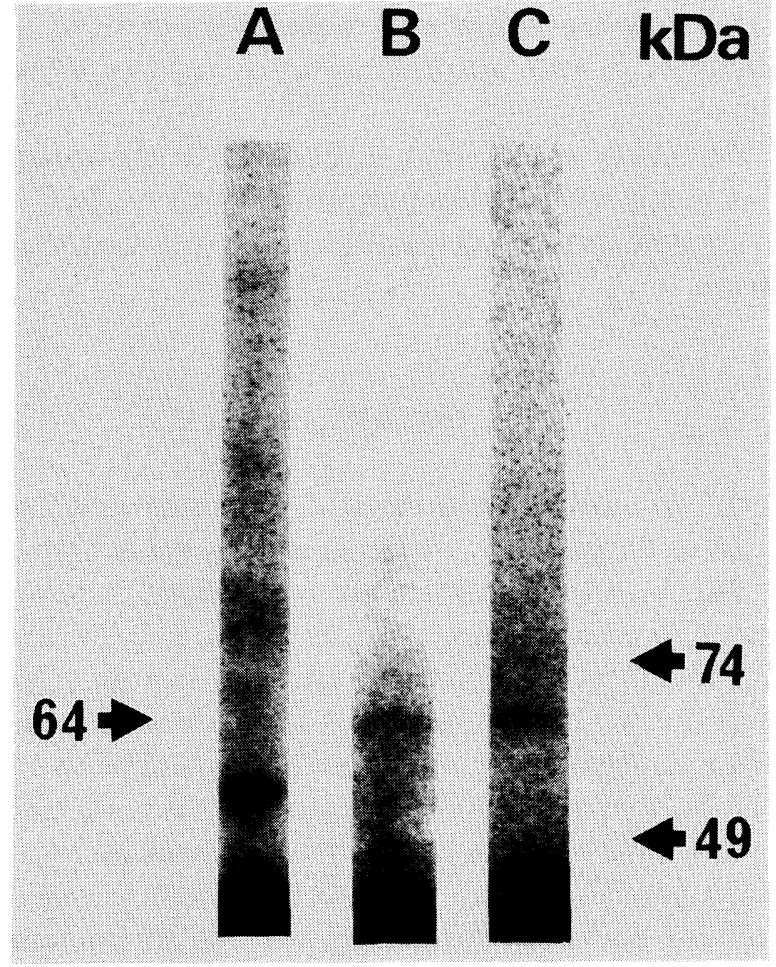

Fig. 2. SDS-PAGE and autoradiography of immune precipitates from solubilized ${ }^{125}$-labeled-In-111 cells (lanes A, B) and TPC- 1 cells (lane C). Immunoprecipitation with immunoglobulins from a healthy control subject (lane A) and a patient (case 8) with non-insulin dependent diabetes mellitus and chronic thyroiditis (lanes $B, C$ ). In lanes $B$ and $C$, a radioactive $64 \mathrm{kDa}$ protein is demonstrated. with In-111 cells in all cases (Fig. 1). Furthermore, ICA were not detected in any case of the nine ICSApositive sera.

As shown in Fig. 2, ICSA-corresponding antigen (a $64 \mathrm{kDa}$ protein band) in In-111 cells was detected in the immunoprecipitation study. When sera from the nine ICSA-positive patients were examined, this band was found in 2/3 NIDDM, 2/3 CT, and 2/3 NIDDM and CT (Table 1). Moreover, when normal thyroid tissue was used in place of In-111 cells (Fig. 2), the $64 \mathrm{kDa}$ band was also detected in 1/3 NIDDM, 1/3 CT, and 2/3 NIDDM and CT (Table 1). In one patient with CT (Case 4 in Table 1) and one patient with NIDDM and CT (Case 8), the $64 \mathrm{kDa}$ protein was precipitated from both In-111 cells and thyroid follicular cells, suggesting possible common antigen(s) in the pancreatic islet and the thyroid. When the normal control sera were tested, the $64 \mathrm{kDa}$ protein band was not observed in either In-111 cells or TPC-1 cells.

To further examine the organ specificity of ICSA, normal liver as a control antigen was tested for reactivity with ICSA. No specific bands including $64 \mathrm{kDa}$ protein were found in any serum of the nine ICSA-positive patients (data not shown), thus indicating the organ specificity of the ICSA to the islet and/or the thyroid.

In the immunofluorescence and the immunoprecipitation method with cells cultured in the

Table 1. Clinical profiles of the nine patients with positive ICSA and analyses of their ICSA and ICSA-corresponding antigen

\begin{tabular}{|c|c|c|c|c|c|c|c|c|c|c|c|c|c|}
\hline \multirow{3}{*}{ Case } & \multirow{3}{*}{ Disease } & \multirow{3}{*}{ Age } & \multirow{3}{*}{ Sex } & \multirow{3}{*}{$\begin{array}{l}\text { Duration } \\
\text { of DM }\end{array}$} & \multirow{2}{*}{\multicolumn{2}{|c|}{$\begin{array}{c}\text { Thyroid auto } \\
\text { antibodies }\end{array}$}} & \multicolumn{4}{|c|}{ Indirect immunofluorescence } & \multicolumn{3}{|c|}{ Immunoprecipitation } \\
\hline & & & & & & & & TPC -1 & $\begin{array}{l}\text { TPC-1 } \\
\text { with }\end{array}$ & ICA & $\begin{array}{c}64 \mathrm{kDa} \\
\text { in }\end{array}$ & $\begin{array}{c}64 \mathrm{kDa} \\
\text { in }\end{array}$ & $\begin{array}{c}\text { Anti-BSA } \\
\text { antibodies }\end{array}$ \\
\hline & & & & & $\mathrm{MCHA}$ & TGHA & & & with In-111 & & & & \\
\hline 1 & NIDDM & 60 & $\mathrm{M}$ & $5-6 \mathrm{y}$. & - & - & \pm & \pm & - & - & - & + & - \\
\hline 2 & NIDDM & 72 & $\mathrm{~F}$ & $10 \mathrm{y}$ & - & - & \pm & - & - & - & + & - & - \\
\hline 3 & NIDDM & 68 & $\mathrm{~F}$ & $12 y$. & - & - & \pm & - & - & - & + & - & + \\
\hline 4 & $\mathrm{CT}$ & 71 & $\mathrm{~F}$ & - & $80^{2}$ & $160^{2}$ & + & \pm & - & - & + & + & + \\
\hline 5 & CT & 64 & $\mathrm{~F}$ & - & $20^{2}$ & - & + & + & - & - & + & - & - \\
\hline 6 & $\mathrm{CT}$ & 68 & $\mathrm{~F}$ & - & $160^{2}$ & 80 & \pm & - & - & - & - & - & + \\
\hline 7 & $\mathrm{NIDDM}+\mathrm{CT}$ & 48 & M & $<1 \mathrm{y}$ & $80^{2}$ & $40^{2}$ & \pm & - & - & - & + & - & + \\
\hline 8 & $\mathrm{NIDDM}+\mathrm{CT}$ & 75 & M & $22 \mathrm{y}$. & $160^{2}$ & $10^{2}$ & \pm & \pm & - & - & + & + & - \\
\hline 9 & NIDDM+CT & 55 & M & $2-3 y$ & $20^{2}$ & $10^{2}$ & + & + & - & - & - & + & - \\
\hline
\end{tabular}

NIDDM, non-insulin dependent diabetes mellitus; CT, chronic thyroiditis; MCHA, microsomal hemagglutination test; TGHA, thyroglobulin hemagglutination test; In-111, hamster insulinoma cell line; TPC-1, human thyroid papillary adenocarcinoma cell line; BSA, bovine serum albumin; ICSA, islet cell surface antibodies; ICA, islet cell cytoplasmic antibodies; +, positive; \pm , weak-positive; -, negative. 
medium containing BSA, the presence of BSA antibodies in the sera should be carefully considered, since the molecular weight of albumin itself $(67$ $\mathrm{kDa}$ ) is close to that of the ICSA-corresponding antigen [22]. In fact, the radioactive band of BSA in the immunoprecipitation study with ${ }^{125}$ I-labeled BSA was detected, irrespective of ICSA, in 1 NIDDM, 2 CT, 1 NIDDM and CT out of the nine tested patients and even in one out of three normal control subjects examined.

As shown in Table 1, the results for the immunoprecipitable $64 \mathrm{kDa}$ band from In-111 or thyroid cells and for the anti-BSA antibodies examination in the nine ICSA-positive patients are summarized together with their clinical profiles. Anti-BSA antibodies were not found in two out of three ICSA-positive patients with NIDDM and CT (Cases 8 and 9). The ICSA of the two cases showed immunofluorescence on TPC-1 cells and recognized the $64 \mathrm{kDa}$ antigen in normal thyroid follicular cells. Furthermore, the ICSA of Case 8 did recognize the $64 \mathrm{kDa}$ antigen of In-111 cells as well, suggesting the presence of $64 \mathrm{kDa}$ antigen common in pancreatic islet cells and thyroid follicular cells in this NIDDM patient associated with CT.

\section{Discussion}

Loss of insulin production is the most important functional characteristic of IDDM, and IDDM has been thought to be caused by the selective destruction of pancreatic $\beta$-cells through autoimmune mechanisms. Among various autoantibodies identified in IDDM patients [6], ICSA have been reported to be $\beta$-cell specific, nonspecies-specific antibodies highly found in patients soon after clinical onset of IDDM or sometimes even before the onset, and to disappear as time passes [23]. As to NIDDM, some Japanese NIDDM cases that have autoantibodies as ICA and/or complement-fixing ICA persistently progress to IDDM (slowly progressive IDDM) [24], suggesting the involvement of autoimmune mechanisms in some type of NIDDM. Previously, we reported that $11(10 \%)$ out of 117 CT patients had NIDDM [25]. This observation is consistent with the studies which reported this association in Caucasians [26]. In this context, the clinical association of NIDDM and CT in Japanese is interesting.

Regarding the detection of ICSA with In-111 cells, good correlation between the results of the indirect immunofluorescence method and those of radioimmunoassay with ${ }^{125}$ I-labeled anti-human IgG antibody (RIA) or of ${ }^{125}$ I-protein A binding assay has been reported [27]. The results of the study by these methods showed positive ICSA in $11 \%$ of NIDDM and also in $41 \%$ of IDDM. These results indicate the usefulness of In-111 cells for ICSA measurement. In the present study, $20 \%$ NIDDM patients and 16\% NIDDM patients associated with CT were ICSA positive.

The $64 \mathrm{kDa}$ protein has been identified as an autoantigen in IDDM patients by immunoprecipitation with isolated human or rat islets labeled with ${ }^{35} \mathrm{~S}$-methionine [28]. But it is not yet known whether the protein is exposed at the outer leaflet or whether it is confined to the cytoplasmic site of the plasma membrane [29]. There has also been reported low expression, or none at all, of the 64 $\mathrm{kDa}$ protein as an autoantigen in IDDM in transformed $\beta$-cells [29]. Nevertheless in the present study on NIDDM, but not IDDM, patients, we detected a $64 \mathrm{kDa}$ protein as an ICSA-corresponding antigen in $\beta$-cells derived from hamster insulinoma, In-111 cells. Furthermore, the ICSA-positive immunofluorescence completely disappeared after prior absorption of each serum with In-111 cells. In addition, ICA were not detected in any of the nine ICSA-positive cases. It is therefore conceivable that the $64 \mathrm{kDa}$ protein which reacted with the IG fraction of the cases is derived from the membrane of In-111 cells, though cell membrane and other cell fractions were used in the immunoprecipitation study. As to the MW of the $64 \mathrm{kDa}$ protein, it is known that $64 \mathrm{kDa}$ is close to that of BSA and BSA in the culture medium readily adheres to islet cells. It has come to be questioned whether the autoantibodies to islet cells detected in the studies which used isolated islet cells or $\beta$ cell lines always express the true antibodies [22]. Furthermore, anti-BSA antibodies which are often observed in diabetic patients as well as normal subjects may bind to BSA on the islet cells or a similarly sized protein on the $\beta$-cell surface [30]. But among the nine ICSA-positive sera tested in the present study, the $64 \mathrm{kDa}$ protein was immunoprecipitated by three patients' sera which did not contain anti-BSA antibodies.

It has been reported that $64 \mathrm{kDa}$ protein may have greater specificity, sensitivity, and predictive value for IDDM than either ICA or anti-insulin an- 
tibodies [31]. IDDM does not develop in CT patients with either ICA or anti-insulin antibodies in the face of the antibodies persistency [32], while IDDM develops in CT patients with $64 \mathrm{kDa}$ protein [31]. In this study, ICSA obtained from six out of nine ICSA-positive patients recognized 64 $\mathrm{kDa}$ protein in In-111 cell membrane, and ICSA from 4 patients also recognized $64 \mathrm{kDa}$ protein in normal thyroid follicular cell membrane. On the other hand, ICSA of Cases 1, 6 and 9 shown in Table 1 did not recognize $64 \mathrm{kDa}$ protein in In-111 cells. A similar dissociation between ICSA and 64 $\mathrm{kDa}$ protein has also been observed in diabetic children and in BB rats [28], suggesting the variable reactivity of the antibodies between and/or within species. Interestingly enough, in one case of NIDDM associated with CT (Case 8), we detected circulating antibodies showing the cell-surface immunofluorescence on both In-111 cells and TPC-1 cells, and prior absorption of the serum with In111 cells abolished the immunofluorescence on TPC- 1 cells. And antibodies to the $64 \mathrm{kDa}$ protein in both In-111 cells and normal thyroid follicular cells were detected in this case, indicating that the antibody-corresponding antigens in both islet $\beta$ cells and thyroid follicular cells are immunologically closely related or identical. This patient has been clinically diabetic for 22 years and his CT was found 16 years after the appearance of diabetes.

Recently, the $64 \mathrm{kDa}$ protein found as an autoantigen in IDDM was identified as the $\gamma$ aminobutyric acid (GABA)-synthesizing enzyme, glutamic acid decarboxylase (GAD), in pancreatic $\beta$ cells [33]. It has been reported that two forms of GAD with molecular weights of 65 and $67 \mathrm{kDa}$ $\left(\mathrm{GAD}_{65}\right.$ and $\left.\mathrm{GAD}_{67}\right)$ exist [34] and some ICA are reactive to GAD in islet cells [35] where $G A D_{65}$ is expressed specifically [36]. In addition, other endocrine cells, such as pituitary cells and adrenal chromaffin cells, are known to have GAD, but are not always confined to $\mathrm{GAD}_{65}$ [37]. Furthermore, it was reported that autoantibodies to a $64 \mathrm{kDa}$ protein isolated from the human thyroid and retroorbital tissue were identified in the sera of patients with thyroid-associated ophthalmopathy [38] and the same autoantibodies cross-reacted with a $64 \mathrm{kDa}$ antigen expressed on the surface of human pancreas cell membranes [39]. But it is not yet clear whether the thyroid $64 \mathrm{kDa}$ protein is similar to the $64 \mathrm{kDa}$ islet autoantigen $\left(\mathrm{GAD}_{65}\right)$ [39]. In any event, it is intriguing that the common 64 $\mathrm{kDa}$ autoantigen is present on both islet $\beta$-cells and thyroid follicular cells. Since recent observations have indicated that the $64 \mathrm{kDa}$ protein detected in IDDM patients is almost exclusively $\mathrm{GAD}_{65}$, the putative $64 \mathrm{kDa}$ protein detected in NIDDM and CT patients remains to be characterized.

Finally, some of the patients associated with NIDDM and CT in this study had ICSA which reacted with the $64 \mathrm{kDa}$ protein of both In-111 cells and thyroid follicular cells, and this fact is interesting in studying the expression of common antigens. The results of this study may therefore, at least in part, explain the autoimmune mechanism in the association of diabetes mellitus and chronic thyroiditis or in polyglandular endocrinopathy.

\section{References}

1. Bottazzo GF, Florin-Christensen A, Doniach D (1974) Islet-cell antibodies in diabetes mellitus with autoimmune polyendocrine deficiencies. Lancet 2: 1279-1283.

2. Bottazzo GF, Dean BM, Gorsuch AN, Cudworth AG, Doniach D (1980) Complement-fixing islet-cell antibodies in type-I diabetes: Possible monitors of active beta-cell damage. Lancet 1: 668-672.

3. Maclaren NK, Huang SW, Fogh J (1975) Antibody to cultured human insulinoma cells in insulin-dependent diabetes. Lancet 1: 997-999.

4. Lernmark $\AA$, Freedman ZR, Hofmann C, Rubenstein $\mathrm{AH}$, Steiner DF, Jackson RL, Winter RJ, Traisman HS (1978) Islet-cell-surface antibodies in juvenile diabetes mellitus. N Engl J Med 299: 375-380.

5. Weetman AP, McGregor AM (1984) Autoimmune thyroid disease: Development in our understanding. Endocr Rev 5: 309-355.

6. Drell DW, Notkins AL (1987) Multiple immunological abnormalities in patients with Type 1 (insulin-dependent) diabetes mellitus. Diabetologia 30: 132-143.

7. Carpenter CCJ, Solomon N, Silverberg SG, Bledsoe T, Northcutt RC, Klinenberg JR, Bennett IL, Harvey AM (1964) Schmidt's syndrome (Thyroid and adrenal insufficiency): A review of the literature and a report of fifteen new cases including ten instances of coexistent diabetes mellitus. Medicine (Oxford) 43: 
153-180.

8. Oka N, Notsu K, Note S, Nabeya N, Kuno S, Sakurami T (1987) Significance of anti-islet cell antibodies in patients with diabetes mellitus and autoimmune thyroid disorders. J Jpn Soc Intern Med 76: 802-809 (In Japanese).

9. Van De Winkel M, Smets G, Gepts W, Pipeleers D (1982) Islet cell surface antibodies from insulin-dependent diabetics bind specifically to pancreatic $B$ cells. J Clin Invest 70: 41-49.

10. Suzuki M, Kawazu S, Negishi K, Watanabe T, Hokama A, Takahashi H, Shunto S, Moritani S, Inoue I, Takei S, Ishii J (1988) Clinical implications of islet cell surface antibodies (ICSA) in non-insulin dependent diabetes mellitus-In relation to pancreatic B cell function and HLA antigens. J Jpn Diab Soc 31: 801-808 (In Japanese with English abstract).

11. Lernmark $\AA$, Sehlin J, Täljedal IB, Kromann $H$, Nerup J (1978) Possible toxic effects of normal and diabetic patient serum on pancreatic B-cells. Diabetologia 14: 25-31.

12. World Health Organization (1980) WHO Expert Committee on Diabetes Mellitus, Second Report, Geneva, World Health Organization, Technical Report Series 646: 1-80.

13. Uchida S, Watanabe $S$, Aizawa T, Kato K, Furuno $A$, Muto $T$ (1976) Induction of papillary ependymomas and insulinomas in the Syrian golden hamster by BK virus, a human papovavirus. Gann 67: 857-865.

14. Satoh N, Kurata Y (1988) Monoclonal antibodies against human thyroid cancer. In: Scientific Report Committee (ed) Cancer Research Institute Report (1985-1987). Kanazawa, Japan, 57.

15. Rabin BS, Nakamura RM (1980) Improved method for detection of anti-tissue antibody by indirect immunofluorescence using fixed tissue. J Clin Lab Immunol 4: 119-124.

16. Schwartz BD, Nathenson SG (1971) Isolation of $\mathrm{H}-2$ alloantigens solubilized by the detergent NP-40. J Immunol 107: 1363-1367.

17. Lowry OH, Rosebrough NJ, Farr AL, Randall RJ (1951) Protein measurement with the folin phenol reagent. J Biol Chem 193: 265-275.

18. Greenwood FC, Hunter WM, Glover JS (1963) The preparation of ${ }^{131} \mathrm{I}$ - labeled human growth hormone of high specific radioactivity. Biochem J 89: 114-123.

19. Kessler SW (1975) Rapid isolation of antigens from cells with a staphylococcal protein A-antibody adsorbent: Parameters of the interaction of antibody-antigen complexes with protein A. A J Immunol 115: 1617-1624.

20. Laemmli UK (1970) Cleavage of structural proteins during the assembly of the head of bacteriophage T4. Nature 227: 680-685.

21. Kurata Y (1967) Immunopathology in autoimmune thyroiditis: Refining of organ-specific antigens. $\mathrm{Tr}$ Soc Path Jap 56: 374-378.

22. Colman PG, Campbell IL, Kay TWH, Harrison LC (1987) 64,000-Mr autoantigen in Type I diabetes. Evidence against its surface location on human islet. Diabetes 36: 1432-1440.

23. Dobersen MJ, Scharff JE, Ginsberg-Fellner F, Notkins AL (1980) Cytotoxic autoantibodies to beta cells in the serum of patients with insulin-dependent diabetes mellitus. N Engl J Med 303: 1493-1498.

24. Kobayashi T, Itoh T, Kosaka K, Sato K, Tsuji K (1987) Time course of islet cell antibodies and $\beta$ cell function in non-insulin-dependent stage of type I diabetes. Diabetes 36: 510-517.

25. Nakabayashi H, Kawato M, Ueda M (1974) Clinical features of chronic thyroiditis. J Jpn Soc Intern Med 63: 1107-1108 (In Japanese).

26. Bastenie PA, Bonnyns M, Vanhaelst L, Nève P (1972) Diseases associated with autoimmune thyroiditis. In: Bastenie PA, Ermans AM (eds) Thyroiditis and Thyroid Function-Clinical, Morphological and Physiopathological Studies. Pergamon Press, Oxford, New York, 1st ed, 261-274.

27. Negishi K (1983) Islet cell surface antibodies(ICSA) radioimmunoassay with insulinoma cell and it's clinical application. J Jpn Diab Soc 26: 485-496 (In Japanese with English abstract).

28. Baekkeskov S, Nielsen JH, Marner B, Bilde T, Ludvigsson J, Lernmark $\AA$ (1982) Autoantibodies in newly diagnosed diabetic children immunoprecipitate human pancreatic islet cell proteins. Nature 298: 167-169.

29. Baekkeskov S, Christie M (1989) Characterization of the $64-\mathrm{kD}$ membrane autoantigen in pancreatic $\beta$ cells. In: Hanahan D, McDevitt HO, Cahill, Jr. GF (eds) Current Communications in Molecular Biology. Cold Spring Harbor Laboratory, New York, 181-186.

30. Savilahti E, Akerblom HK, Koskimies S (1988) Children with newly diagnosed insulin-dependent diabetes mellitus have increased levels of cows' milk antibodies. Diabetes Res 7: 137-140.

31. Atkinson MA, Maclaren NK, Scharp DW, Lacy PE, Riley WJ (1990) 64,000 Mr autoantibodies as predictors of insulin-dependent diabetes. Lancet 335: 1357-1360.

32. Betterle C, Presotto F, Pedini B, Moro L, Slack RS, Zanette F, Zanchetta R (1987) Islet cell and insulin autoantibodies in organ-specific autoimmune patients. Their behaviour and predictive value for the development of Type 1 (insulin-dependent) diabetes mellitus. A 10-year follow-up study. Diabetologia 30: 292-297.

33. Baekkeskov S, Jan Aanstoot H, Christgau S, Reetz A, Solimena M, Cascalho M, Folli F, Richter-Olesen H, De Camilli P (1990) Identification of the $64 \mathrm{~K}$ autoantigen in insulin-dependent diabetes as the 
GABA-synthesizing enzyme glutamic acid decarboxylase. Nature 347: 151-156.

34. Erlander MG, Tillakaratne NJK, Feldblum S, Patel $\mathrm{N}$, Tobin AJ (1991) Two genes encode distinct glutamate decarboxylases with different responses to pyridoxal phosphate. Neuron 7: 91-100.

35. Atkinson MA, Kaufman DL, Newman D, Tobin AJ, Maclaren NK (1993) Islet cell cytoplasmic autoantibody reactivity to glutamate decarboxylase in insulin-dependent diabetes. J Clin Invest 91: 350356.

36. Petersen JS, Russel S, Marshall MO, Kofod H, Buschard K, Cambon N, Karlsen AE, Boel E, Hagopian WA, Hejnes KR, Moody A, Dyrberg T,
Lernmark ̊̊, Madsen OD, Michelsen BK (1993) Differential expression of glutamic acid decarboxylase in rat and human islets. Diabetes 42: 484-495.

37. Erdö SL, Wolff JR (1990) $\gamma$ Aminobutyric acid outside the mammalian brain. J Neurochem 54: 363-372.

38. Salvi M, Miller A, Wall JR (1988) Human orbital tissue and thyroid membranes express a $64 \mathrm{kDa}$ protein which is recognized by autoantibodies in the serum of patients with thyroid-associated ophthalmopathy. FEBS Letters 232: 135-139.

39. Salvi M, Fukazawa H, Bernard N, Hiromatsu Y, How J, Wall JR (1988) Role of autoantibodies in the pathogenesis and association of endocrine autoimmune disorders. Endocrine Rev 9: 450-466. 